Article

\title{
Modelling the Relation between Managers, Shadow Cost of External Finance and Corporate Investment
}

\begin{abstract}
Alfonsina Iona
School of Economics and Finance, Queen Mary University of London, London E1 4NS, UK; a.iona@qmul.ac.uk

Received: 7 October 2019; Accepted: 30 October 2019; Published: 4 November 2019

check for updates

Abstract: This paper provides a theoretical framework for studying the impact of self-interested managers on the level of corporate investment. I extend the standard neoclassical model of firm value maximization to incorporate the effect of misaligned managers on corporate investment via a firm's profit, adjustment costs of capital and shadow cost of external finance. Under some assumptions, commonly made by the relevant literature, the model shows that the intensity of agency conflicts between misaligned managers and outside shareholders affects a firm's investment decisions generating either under or overinvestment with respect to a perfect capital market and driving a higher cost of external finance.
\end{abstract}

Keywords: misaligned managers; cost of finance; corporate investment

\section{Introduction}

In the neoclassical microeconomic model of investment [1,2], the firm's choice of the optimal capital stock (i.e., optimal investment) can be solved without referring to financial factors. In this model (see the Figure 1 below), the demand curve of capital, $D$, is downward sloping in the cost of funds, while its location is determined by the firm's investment opportunities (i.e., the expected marginal profitability of capital). The supply curve of capital, $S$, is instead determined by the risk-adjusted real market interest rate, $r$. The optimal stock of capital is $K^{*}$, where $D=S$. At $K^{*}$, the expected marginal profitability of capital equals the marginal cost of capital and the firm value is maximized. Ceteris paribus, as investment opportunities improve, the demand of capital shifts to the right, increasing $K^{*}$. Similarly, an increase in the market interest rate shifts the $S$ curve upward, reducing the desired capital stock, $K^{*}$. This basic story allows no role for the firm financial structure per se to affect the investment decisions. This because the firm cost of capital is established in the capital markets and it is independent of the firm financial structure. The opportunity cost of internal funds is simply perceived by the firm to be the market interest rate and the firm can borrow and lend at that rate in the capital market. This argument holds true because of the underlying assumption that there are no informational asymmetries-shareholders and outside financiers have the same information about the firm's profit, investment opportunities and riskiness of projects. 


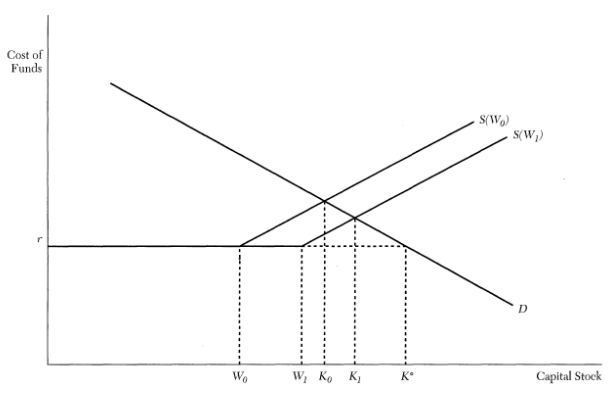

Figure 1. The market for capital.

Following this line of economic research, since the mid-1960s, most applied finance work isolated real investment decisions from financing decisions. The finance justification of this strategy was the Modigliani and Miller [2] theorem of irrelevance of capital structure for investment under the assumptions of perfect information on capital markets; no costs of raising capital; no taxes; no transaction costs; no cost of bankruptcy; no cost in monitoring debt; firms in the same risk class offer the same return. The central prediction of the Modigliani-Miller theory was that a firm's capital structure will not affect its market value and cost of capital in frictionless capital markets. Therefore, investment decisions, motivated by the maximization of shareholders' claims, are independent of the ways they are financed. Applied to capital investment, this basic result offered an underpinning of the neoclassical investment theory, where the optimal capital stock is determined regardless of the financial factors.

The $q$-theory approach, pioneered by Tobin [3] and extended by Hayashi [4] to models of investment with convex adjustment costs of capital and concave profit functions, offers another formulation for the neoclassical investment model. Here, optimal investment is determined only by the market value of the capital stock, $q$, which summarizes the expected marginal profitability of capital. The tradition in the $q$ literature is that, under a number of assumptions such as, perfectly competitive markets, homogeneity of fixed capital, linear homogeneity of production and adjustment costs and no financial frictions [4], the average $Q$, computed by using financial market data, can be used as a good proxy for the marginal $q$. A great deal of mathematical models has then formalized the firm optimal level of investment in such a perfect capital market where firms face no financial frictions (see Section 2.1).

However, while in the approaches above, a firm's cost of capital is set in centralized securities markets and it is independent of the firm's capital structure, since the mid-1980s, new theories of capital structure— the Pecking order theory andAgency theory—demonstrated the relevance of capital structure for the cost of capital and the level of investment, under asymmetric information. The underlying idea is that in a real capital market, informational asymmetries and agency problems cause the external finance cost to be higher than that of internal finance. Consequently, investment is no longer independent of the way it is financed.

To give an intuition of this argument, think of the $S$ curve as having two components: the first is an horizontal segment at $r$, up to a level of funds, $W_{0}$, the entrepreneur's net worth. In this range, no agency costs arise and lenders' required rate of return equals the market real interest rate. When the risk of opportunistic behavior is present, instead, uncollateralized lending requires that lenders be compensated for information costs. Hence for levels of net worth greater than $W_{0}$, the $S$ curve is upward-sloping, that is, the shadow cost of uncollateralized external financing exceeds that of internal financing. The slope of the $S$ curve depends on the information costs of external financing: the higher these information costs the steeper the $S$ curve. Consequently, the stock of capital, $K_{0}$, is lower than the optimal capital stock, $K^{*}$; that is, there is underinvestment relative to the setting with no information costs.

The figure shows also how, when informational problems are taken into account, investment is no longer independent on the level of internal funds. Indeed, when net worth increases from $W_{0}$ to $W_{1}$, 
the supply-of-funds curve shifts from $S\left(W_{0}\right)$ to $S\left(W_{1}\right)$. The increase in net worth, holding constant both information costs and investment opportunities, increases the equilibrium capital stock from $K_{0}$ to $K_{1}$. Note that, an increase in net worth does not affect investment of firms with no information costs. However, it may lead to greater investment, even greater than the first-best level (if managers are misaligned), in firms with high information costs.

In line with the above argument, the existing finance models of investment have focused on costs of adverse selection and moral hazard in generating a gap between the cost of external (debt and equity) and internal funds (cash or cash flow). The idea is that managers of large corporations may pursue their own interest, which may diverge from that of outside shareholders. In presence of incentive problems and costly monitoring of managerial actions, outside shareholders require a higher interest rate in order to be compensated for the monitoring costs of managers [5-8]. As a consequence, from a managers' perspective, internal financing may be more convenient than external financing because it enables self-interested managers to pursue their own personal benefits, by avoiding the discipline exerted by the debt. Jensen $[9,10]$ argues that this will make managers wanting to spend all available funds on investments, causing over-investment. However, the models in References [11-13], assuming that the managerial private benefits of control are proportional to the amount the firm invests or to the gross output from investment, predict that there will be overinvestment only when the level of free cash flow relative to the first-best level of investment is higher than expected but underinvestment otherwise. Therefore, the availability of internal funds is crucial in determining the impact of the agency conflicts on investment decisions.

The agency conflict may arise from different kinds of managers' behavior such as, empire-building tendency [9,10], empire-preservation, entrenchment and diversification [14], short-termism [15], the desire for a quiet life [16,17] and overconfidence. For example, Reference [18], by modelling overconfident managers, shows that overconfidence can lead to overinvestment but also to costly-external finance and underinvestment.

It is worth to point out that all these studies have formalized, with different models and under different assumptions, the way agency problems affect investment. However, there is no a very simple reduced-form model which is able to capture the essence of what these theories say about investment. In this paper I provide such a model. In particular, I propose a general theoretical framework for studying the impact of misaligned managers on the level of corporate investment. I do so by extending the standard model of Tobin's $q$ to incorporate the effect of misaligned managers on corporate investment via a firm's profit, adjustment costs of capital and shadow cost of external finance. Under assumptions based on the relevant theoretical literature and in line with predictions from previous studies, the model shows that the intensity of agency conflicts between misaligned managers and outside shareholders affects a firm's investment decisions generating either under or overinvestment with respect to a perfect capital market and driving a higher cost of external finance. These outcomes may have important implications for the firm value.

\section{Theory}

\subsection{Corporate Investment in a Perfect Capital Market}

Corporate finance models predict that in equilibrium, that is, in a perfect capital market, there is no asymmetric information between a firm and the financial market, nor meaningful conflict of interest between managers and shareholders: managers and shareholders interests are aligned. They both aim to maximize the firm value, either because managers act in the interest of shareholders or because they own shares of the company. Financial economists, to derive the optimal level of investment in that market, commonly use the standard $q$ model of investment [3]. To see how this model generates a target of investment, let's consider a generalization of the Tobin $q$-model, where shareholders, by taking into account the constraint of capital accumulation, choose the level of investment which maximizes 
the expected discounted value of current and future cash flows. At time $t$, the firm value, $V_{t}($.$) , is given$ by:

$$
V_{t}\left(K_{t}\right)=\max _{\left\{I_{\tau}\right\}_{\tau=0}^{\infty}} E_{t}\left\{\sum_{\tau=0}^{\infty} \beta^{\tau}\left[\pi\left(K_{t+\tau}\right)-I_{t+\tau}-C\left(I_{t+\tau}\right)\right] / \Omega_{t}\right\}
$$

where $E\{$.$\} is the operator of expectation conditional on the set of information \Omega_{t}$, available at time $t ; \beta^{\tau}$ is the constant discount factor; $\pi($.$) is a profit function assumed as concave in capital stock$ and already maximized with respect to labor. $C(I)$ is the adjustment cost of capital. The price of the investment good is normalized to 1 . In these models it is also assumed a perfectly competitive product market and a perfect capital market. Capital stock, $K_{t}$, is a quasi-fixed input whose law of accumulation follows

$$
K_{t}=K_{t-1}+I_{t},
$$

The depreciation rate of capital is assumed to be zero. Given these assumptions, the FOC with respect to investment is:

$$
1+\frac{\partial C\left(I_{t}\right)}{\partial I_{t}}=E_{t}\left\{\sum_{\tau=0}^{\infty} \beta^{\tau}\left[\frac{\partial \pi\left(K_{t+\tau}\right)}{\partial K_{t+\tau}}\right]\right\}
$$

Equation (3) states that the firm should invest up to the point where the marginal cost capital (LHS) equals the expected discounted value of the future marginal profitability of capital (RHS).

In order to obtain an investment specification from the first-order condition, we must posit an explicit form for the adjustment costs function $C($.$) The q$ literature uses to specify firm's adjustment costs that are linearly homogenous in $I$, so that marginal $q$ (unobservable) - expected marginal profitability of capital - will be equal to the average $Q$ (observable) as in Reference [4] (This is possible under the Hayashi's assumptions, as explained before.):

$$
q=E_{t} \sum_{\tau=0}^{\infty} \beta^{\tau}\left[\frac{\partial \pi\left(K_{t+\tau}\right)}{\partial K_{t+\tau}}\right]=\frac{\partial \pi_{t}\left(K_{t}\right)}{\partial K_{t}}=Q
$$

and a convenient parameterization for the adjustment costs is the following:

$$
C_{t}\left(I_{t}\right)=\frac{\alpha}{2}\left[I_{t}-a I_{t-1}-\lambda\right]^{2}
$$

where $\alpha, a$ and $\lambda$ are parameters. As in References [19-21], the equation above includes the term $a I_{t-1}$, which measures the persistency and irreversibility in the investment, leading to a partial adjustment model. Parameter $\lambda$ is the firm-specific level of investment which minimizes the adjustment costs.

The first order condition of Equation (5) with respect to I yields the marginal adjustment cost of investment as:

$$
\frac{\partial C_{t}\left(I_{t}\right)}{\partial I_{t}}=\alpha\left[I_{t}-a I_{t-1}-\lambda\right]
$$

By replacing Equations (6) and (4) in Equation (3) yields the firm's optimal level of investment:

$$
I_{t}=\lambda+a I_{t-1}+\frac{1}{\alpha}[Q-1]
$$

This equation suggests that, when the Hayashi's assumptions hold, the optimal level of investment, in a perfect capital market, depends on the adjustment costs (via a) and average profitability of capital (via $\frac{1}{\alpha}$ ) only. In this setting, where financial frictions are irrelevant for investment decisions, changes in internal sources have no effects on investment, once $Q$ is controlled for [4,22]: $Q$ is the best indicator of future expected profitability in the sense that the effect of other financial variables is already included in it. 
A wide empirical literature has used to estimate the corresponding empirical model below by using firm (i) panel data [22-24].

$$
I_{i t}=\lambda+a I_{i t-1}+\frac{1}{\alpha} Q_{i t}+\varepsilon_{i t}
$$

However, if one expects the residuals from the regression of $I$ on $Q$ being correlated with changes in cash flow, such correlation would reject the frictionless $Q$ model, while suggesting an alternative investment model in which financing constraints play a role. This is the main reason why a very large literature has proliferated on the investment-cash flow sensitivity [23-32]. This research has pointed out that, in presence of financing frictions, investment decisions depend not only on $Q$ but also on the availability of internal finance and cost of external finance.

\subsection{Corporate Investment in Presence of Misaligned Managers}

All previous studies have formalized, with different models and under different assumptions, the way agency problems affect investment. However, there is no a general simple reduced-form model which is able to nest all the hypotheses these theories make about investment and informational problems. In this paper, I provide such a model, that is, a general theoretical framework for studying the impact of misaligned managers on the level of corporate investment. In particular, I extend the baseline $q$ model of investment to incorporate the effect of capital market imperfections arising from the agency conflict between misaligned managers and shareholders. I assume, in the spirit of References [12,13], that managers derive private benefits from gross investment output and these in turn affect the speed of adjusting the capital to the optimal capital stock.

In order to model this idea, let's consider the generalization of the standard $q$ model of investment, originally due to References $[3,4]$, where managers choose the level of investment which maximizes the expected discounted value of dividends:

$$
V_{t}\left(K_{t}, \rho_{t}\right)=\max _{\left\{I_{\tau}\right\}_{\tau=0}^{\infty}} E_{t}\left\{\sum_{\tau=0}^{\infty} \beta^{\tau}\left[\pi\left(K_{t+\tau}, \lambda_{t+\tau}\right)-I_{t+\tau}-C\left(I_{t+\tau}, \rho_{t+\tau}\right)\right] \mid \Omega_{t}\right\},
$$

subject to the capital accumulation constraint

$$
K_{t}=K_{t-1}+I_{t}
$$

and the financial constraint

$$
\forall \tau \geq 0 \quad D_{t}=\pi\left(K_{t+\tau}, \rho_{t+\tau}\right)-I_{t+\tau}-C\left(I_{t+\tau}, \rho_{t+\tau}\right) \geq 0
$$

The second constraint is introduced via a non-negative constraint on dividends. This constraint implies that since debt and equity financing is costly, due to capital market imperfections, the firm has to use retained earnings to finance investment. The multiplier on this constraint will be equal to the shadow cost of raising external finance (or opportunity cost of internal finance).

The depreciation rate of capital is assumed to be zero. The index $i$ has been omitted for ease of exposition; $E\{$.$\} is the expectation operator conditional on the information available at time t$, $\Omega_{t} ; \beta^{\tau}$ is the internal constant discount factor; $\pi($.$) is a restricted profit function, that is maximized$ with respect to other inputs; the price of the investment good is normalized to 1. Most importantly, $\rho$ measures the intensity of agency problems between managers and shareholders, that is, the private benefits from the managerial control. 
The Lagrange multipliers are $\mu_{t}$ and $\gamma_{t}$. The first is the shadow cost of external finance, while the second is the shadow cost of capital accumulation.

$$
\begin{aligned}
\mathcal{L}= & \sum_{\tau=0}^{\infty} \beta^{\tau}\left\{\left[\pi\left(K_{t+\tau}, \rho_{t+\tau}\right)-I_{t+\tau}-C\left(I_{t+\tau}, \rho_{t+\tau}\right)\right]\left(1+\mu_{t+\tau}\right)+\right. \\
& \left.\gamma_{t+\tau}\left(K_{t+\tau}-K_{t+\tau-1}-I_{t+\tau}\right)\right\}
\end{aligned}
$$

The FOC with respect to investment at $\tau=0$ is:

$$
\text { (i) } \frac{\partial \mathcal{L}}{\partial I_{t}}=0=>\left(1+\frac{\partial C\left(I_{t}, \rho_{t}\right)}{\partial I_{t}}\right)\left(1+\mu_{t}\right)=\gamma_{t}
$$

The FOC with respect to capital at $\tau=0$ is:

$$
\text { (ii) } \frac{\partial \mathcal{L}}{\partial K_{t}}=0=>\left(1+\mu_{t}\right) \frac{\partial \pi_{t}}{\partial K_{t}}=\gamma_{t}-\beta E_{t} \gamma_{t+1}
$$

By defining:

$$
x_{t}=\left(1+\mu_{t}\right) \frac{\partial \pi_{t}}{\partial K_{t}}
$$

Equation (14) becomes:

$$
x_{t}=\gamma_{t}-\beta E_{t} \gamma_{t+1}
$$

Solving it forward yields:

$$
E_{t}\left(x_{t+1}\right)=E_{t} \gamma_{t+1}-\beta E_{t} \gamma_{t+2}
$$

By multiplying Equations (16) and (17) by $\beta$-which allows to eliminate the term $E_{t} \gamma_{t+1}$-and summing them we get:

$$
x_{t}+\beta E_{t}\left(x_{t+1}\right)=\gamma_{t}-\beta^{2} E_{t} \gamma_{t+2}
$$

By repeating this operation for a finite number of times, $n$, it yields:

$$
\sum_{\tau=0}^{n}(\beta)^{\tau} E_{t} x_{t+\tau}=\gamma_{t}-\beta^{n+1} E_{t} \gamma_{t+n+1}
$$

Using the assumption of no bubbles:

$$
\lim _{n \rightarrow \infty} \beta^{n+1} E_{t} \gamma_{t+n+1}=0
$$

We can now go to infinity:

$$
\sum_{\tau=0}^{\infty} \beta^{\tau} E_{t} x_{t+\tau}=\gamma_{t}
$$

Replacing $x_{t}$ by its formula and using the first order conditions, we obtain:

$$
\sum_{\tau=0}^{\infty}(\beta)^{\tau} E_{t}\left(1+\mu_{t+\tau}\right)\left[\frac{\partial \pi_{t+\tau}}{\partial K_{t+\tau}}\right]=\gamma_{t}=\left(1+\frac{\partial C_{t}}{\partial I_{t}}\right)\left(1+\mu_{t}\right)
$$

The equation above can simply be written as:

$$
\sum_{\tau=0}^{\infty}(\beta)^{\tau} E_{t} \theta_{t}\left[\frac{\partial \pi_{t+\tau}}{\partial K_{t+\tau}}\right]=\gamma_{t}=\left(1+\frac{\partial C_{t}}{\partial I_{t}}\right)
$$


where $\theta_{t}=\frac{\left(1+\mu_{t+\tau}\right)}{\left(1+\mu_{t}\right)}$ is the shadow cost of external finance between $t$ and $t+\tau$. When the firm is financially constrained, $\mu_{t}>\mu_{t+\tau}$, then the discount factor, $\theta_{t}$, decreases and the firm invest tomorrow rather than today. When the the firm is never constrained $\mu_{t}=\mu_{t+\tau}=0$ for all $t$. and $\theta_{t}=1$.

Since we assume that the uncertainty in the model is exclusively due to $\rho$, which is perceived as permanent and that the internal discount factor is constant over time, the expected marginal profitability of capital will be equal to the current marginal profitability of capital:

$$
\sum_{\tau=0}^{\infty}(\beta)^{\tau} E_{t}\left[\frac{\partial \pi\left(K_{t+\tau}, \rho_{t+\tau}\right)}{\partial K_{t+\tau}}\right]=A * \frac{\partial \pi_{t}\left(K_{t}, \rho_{t}\right)}{\partial K_{t}}
$$

with $A=\sum_{\tau=0}^{\infty}(\beta)^{\tau}=\frac{1}{1-\beta}$ Equation (23) will then be equal to

$$
q_{t}=\theta_{t}\left(\frac{1}{1-\beta}\right)\left[\frac{\partial \pi_{t+\tau}}{\partial K_{t+\tau}}\right]=\gamma_{t}=\left(1+\frac{\partial C_{t}}{\partial I_{t}}\right)
$$

We need now to specify the adjustment cost function and the profit function. The former is now assumed to be:

$$
C_{t}\left(I_{t}, \rho_{t}\right)=\frac{\alpha}{2}\left[I_{t}-a I_{t-1}-\lambda+\rho\right]^{2}
$$

where $\rho$ is now a factor, that is, the managerial private benefits from control which increase the level of investment at which adjustment costs are minimized, since managers capture a fraction of investment output for private benefit. Therefore,

$$
\frac{\partial C_{t}\left(I_{t}, \rho_{t}\right)}{\partial I_{t}}=\alpha\left[I_{t}-a I_{t-1}-\lambda+\rho\right]
$$

The profit function is specified as:

$$
\pi\left(K_{t}, \rho_{t}\right)=\max _{K_{t}}\left[p_{t} X_{t}\left(K_{t}\right)(1+\rho)\right]
$$

where $\pi($.$) is a restricted net profit function, that is, already maximized with respect to labour; X_{t}$ is the firm's output. In the spirit of References [12,13], we add $(1+\rho)$ to the objective function to capture the hypothesis that managers derive private benefits from the net output, with $\rho$ measuring the intensity of the agency conflict. Solving the maximization problem in Equation (28) gives an expression for the marginal profitability of capital:

$$
\frac{\partial \pi_{t}}{\partial K_{t}}=p_{t} \frac{\partial X_{t}}{\partial K_{t}}(1+\rho)
$$

It is worth pointing that, in presence of agency conflicts, the marginal profitability of capital is no longer equal to the average profitability of capital, as it is the case in a perfect capital market. More specifically, in this case of misaligned managers, for any additional unit of capital, the marginal increase in profit is now higher by $\rho\left(\frac{\partial X_{t}}{\partial K_{t}}\right)$ because managers need to capture a fraction of profits from the investment [12].

Plugging Equations (29) and (27) in Equation (25) yields:

$$
\begin{aligned}
q_{t} & =\theta_{t}\left(\frac{1}{1-\beta}\right)\left[\frac{\partial \pi_{t}}{\partial K_{t}}\right]=\left(1+\frac{\partial C_{t}}{\partial I_{t}}\right) \\
q_{t} & =\theta_{t}\left(\frac{1}{1-\beta}\right)\left[p_{t} \frac{\partial X_{t}}{\partial K_{t}}(1+\rho)\right]=1+\alpha\left[I_{t}-a I_{t-1}-\lambda+\rho\right] \\
q_{t} & =\theta_{t}\left(\frac{1+\rho}{1-\beta}\right)\left[p_{t} \frac{\partial X_{t}}{\partial K_{t}}\right]=1+\alpha\left[I_{t}-a I_{t-1}-\lambda+\rho\right] \\
q_{t} & =\frac{\theta_{t}}{\alpha}\left(\frac{1+\rho}{1-\beta}\right)\left[p_{t} \frac{\partial X_{t}}{\partial K_{t}}\right]=\frac{1}{\alpha}+I_{t}-a I_{t-1}-\lambda+\rho
\end{aligned}
$$


Therefore, the theoretical equation of $I_{t}$ will be:

$$
I_{t}=\lambda+a I_{t-1}-\rho-\frac{1}{\alpha}+\frac{\theta_{t}}{\alpha}\left(\frac{1+\rho}{1-\beta}\right)\left[p_{t} \frac{\partial X_{t}}{\partial K_{t}}\right]
$$

In the model, financing constraints will affect investment by modifying the firm stochastic discount factor associated with the external finance premium $\theta$. Since we cannot directly observe this factor, we assume that it is a function of firm-specific level of financing constraints $F C$ (the wedge it faces between the cost of internal and external finance) as follows:

$$
\theta_{t}=\varphi_{0}+\left(\varphi_{1}+\varphi_{2} \rho\right) F C
$$

where $\varphi_{0}$ is the constant firm-specific discount factor. When the firm is not financially constrained at all and does not experience agency problems, $F C$ is zero and $\theta_{t}=\varphi_{0}=1$, that is, the effective discount factor is given by $\beta$ (the internal discount factor). The idea is that the higher the degree of financing constraints the larger $\varphi_{1}$. However, the higher the intensity of agency conflicts between managers and shareholders, $\rho$, the higher the shadow cost of external finance and hence the impact of $F C$ on the discount factor- $\varphi_{2}$.

The interpretation of the investment equation is hence straightforward: in presence of a wedge between the cost of internal and external finance and self-interested managers, the target level of investment, in Equation (31), will be affected by $\rho$ in different ways. On the one hand, $\rho$ has the power of affecting the speed of adjustment of the investment to its target (via adjustment costs of capital). As an example, the higher the managerial control of internal funds (cash stock) the higher may be the incentive of misaligned managers to use cash stock to increase their perquisites or their private benefits, rather than for investing in profitable projects. Investment will then decrease by the intensity of agency conflicts, $\rho$, likely driving under-investment. On the other hand, the presence of an agency problem increases the stochastic discount factor, $\theta_{t}=\frac{\left(1+\mu_{t+\tau}\right)}{\left(1+\mu_{t}\right)}$ associated with the external finance premium by causing the firm to invest more today than tomorrow (likely overinvestment). Notice that, when $\rho$ is zero, the two effects cancel each other. If the two effects do not cancel each other completely, they have the potential to mitigate the effect of the other. However, the magnitude of the investment will also be affected by the amount of free cash flow available to managers.

Therefore, according to the model and consistently with previous literature, the model can generate underinvestment or overinvestment today, depending on which of the two effects of $\rho$ (via the adjustment costs or discount factor) prevails and depending on whether the output generates a level of cash flow higher than that needed to finance the optimal level of investment. The main implication of the underinvestment or over investment is that the firm value will deviate from its first-bet level.

\section{Conclusions}

In this paper, firstly I have described how, in the standard model of a perfect capital market with no informational asymmetries and agency conflicts between managers and shareholders, the target level of investment depends on the adjustment costs of capital and marginal profitability of capital only. Then, I have provided a general theoretical framework for studying the impact of misaligned managers on the level of corporate investment by extending the neoclassical model to incorporate both a wedge between the cost of internal and external finance and the presence of managers whose interests are not aligned with those of shareholders. The solution of the model shows that the intensity of agency conflicts between self-interested managers and shareholders may cause under or overinvestment with respect to a perfect capital market and may drive a higher shadow cost of external finance.

It is known that without agency problems, the maximization of the shareholder value is straightforward. On the contrary, in presence of agency conflicts, there is no guarantee that the firm value will be maximized. Therefore, the corporate governance rules must be designed to mitigate and reduce the effects of these conflicts. These rules may predict to restructure the board of 
directors, because the higher the percentage of outsider directors in the board the less severe the agency conflicts [33,34]. They may also be directed to increase the managerial ownership, because the larger the managerial ownership, the less the scope for managerial opportunism [14]. Corporate governance rules may, in addition, reshape the executive compensation packages [35-37] or increase the firm level of debt $[9,10]$, which would reduce the "free cash-flow" in the hands of managers. The main difficulty of this latter measure is that too much debt means high costs of financial distress and then need to revert to equity [38-41]. This would make desirable to reduce the cost of equity issues. Arguably, the design of efficient corporate governance rules, able to reestablish the equilibria, rests in the hands of corporations and their CEOs.

Funding: This research received no external funding.

Conflicts of Interest: The author declares no conflict of interest.

\section{References}

1. Hall, R.; Jorgenson, D.W. Tax policy and investment behavior. Am. Econ. Rev. 1967, 57, 391-414.

2. Jorgenson, W.D. Capital theory and investment behavior. Am. Econ. Rev. 1963, 53, 247-259.

3. Tobin, J. A general equilibrium approach to monetary theory. J. Money Credit Bank. 1969, 1, 265-293. [CrossRef]

4. Hayashi, F. Tobin's marginal q and average q: A neoclassical interpretation. Econometrica 1982, 50, 213-224. [CrossRef]

5. Akerlof, G. The market for lemons: Quality and the market mechanism. Q. J. Econ. 1970, 84, 488-500. [CrossRef]

6. Jaffee, D.M.; Russell, T. Imperfect information, uncertainty, and credit rationing. Q. J. Econ. 1976, 90, 651-666. [CrossRef]

7. Myers, S.; Majluf, N. Corporate financing decisions when firms have investment information that investors do not. J. Financ. Econ. 1984, 13, 187-221. [CrossRef]

8. Stiglitz, J.E.; Weiss, A. Credit rationing and markets with imperfect information. Am. Econ. Rev. 1981, 71, 393-411.

9. Jensen, M.C. Agency costs of free cash flow, corporate finance, and takeovers. Am. Econ. Rev. 1986, 76, 323-329.

10. Jensen, M.C. The modern industrial revolution, exit, and the failure of internal control systems. J. Financ. 1993, 48, 831-880. [CrossRef]

11. Harris, M.; Raviv, A. Capital structure and the informational role of debt. J. Financ. 1990, 45, 321-350. [CrossRef]

12. Hart, O.; Moore, J. Property rights and the nature of the firm. J. Political Econ. 1990, 98, 1119-1158. [CrossRef]

13. Stulz, R. Managerial discretion and optimal financing policies. J. Financ. Econ. 1990, 26, 3-27. [CrossRef]

14. Shleifer, A.; Vishny, R.W. Management entrenchment: The case of manager-specific investments. J. Financ. Econ. 1989, 25, 123-139. [CrossRef]

15. Narayanan, M.P. Managerial incentives for short-term results. J. Financ. 1985, 40, 1469-1484. [CrossRef]

16. Bertrand, M.; Mullainathan, S. Enjoying the quiet life? Corporate governance and managerial control. J. Political Econ. 2003, 111, 1043-1075. [CrossRef]

17. Iona, A. Managers' empire preservation behaviour and corporate investment. Phys. Life Rev. 2017, 22, 32-34. [CrossRef]

18. Heaton, J.B. Managerial Optimism and Corporate Finance; Working Paper; University of Chicago: Chicago, IL, USA, 1998.

19. Aiello, F.; Iona, A.; Leonida, L. Regional infrastructure and firm investment. Theory and empirical evidence for Italy. Empir. Econ. 2012, 42, 835-862 . [CrossRef]

20. Baum, C.F.; Caglayan, M.; Talavera, O. Uncertainty determinants of firm investment. Econ. Lett. 2008, 98, 282-287. [CrossRef]

21. Love, I. Financial development and financing constraints: International evidence from a structural investment model. Rev. Financ. Stud. 2003, 16, 765-791. [CrossRef]

22. Hubbard, R.G. Capital market imperfections and investment. J. Econ. Lit. 1998, 36, 193-225. 
23. Fazzari, S.M.; Hubbard, R.G.; Petersen, B.C. Financing constraints and corporate investment. Brook. Pap. Econ. Act. 1988, 1, 141-195. [CrossRef]

24. Fazzari, S.M.; Hubbard, R.G.; Petersen, B.C. Investment-cash flow sensitivities are useful: A comment on Kaplan and Zingales. Q. J. Econ. 2000, 115, 695-705. [CrossRef]

25. Adelino, M.; Lewellen, K.; Sundaram, A. Investment decisions of nonprofit firms: Evidence from hospitals. J. Financ. 2015, 70, 1583-1628. [CrossRef]

26. Ağca, S..; Mozumdar, A. Investment-cash sensitivity: Fact or fiction? J. Financ. Quant. Anal. 2017, 52, 1111-1141. [CrossRef]

27. Bond, S.R.; Söderbom, M. Conditional investment-cash flow sensitivities and financing constraints. J. Eur. Econ. Assoc. 2013, 11, 112-136. [CrossRef]

28. Cleary, S. The relationship between firm investment and financial status. J. Financ. 1999, 54, 673-692. [CrossRef]

29. Cleary, S.; Povel, P.; Raith, M. The u-shaped investment curve: Theory and evidence. J. Financ. Quant. Anal. 2007, 42, 1-39. [CrossRef]

30. Kaplan, S.N.; Zingales, L. Do investment-cash flow sensitivities provide useful measures of financing constraints? Q. J. Econ. 1997, 112, 169-215. [CrossRef]

31. Kaplan, S.N.; Zingales, L. Investment-cash flow sensitivities are not valid measures of financing constraints. Q. J. Econ. 2000, 115, 707-712. [CrossRef]

32. Lewellen, J.; Lewellen, K. Investment and cash flow: New evidence. J. Financ. Quant. Anal. 2016, 51, 1135-1164. [CrossRef]

33. Iona, A.; Leonida, L.; Ventouri, A. Does executive ownership lead to excess target cash? The case of U.K. firms. Corp. Gov. 2017, 17, 876-895 [CrossRef]

34. Iona, A.; Leonida, L. Suboptimal financial policies and executive ownership in the UK. Evidence from a pre-crisis. Corp. Gov. 2016, 16, 187-210 [CrossRef]

35. Davies, J.R.; Hillier, D.; McColgan, P. Ownership structure, managerial behavior and corporate value. J. Corp. Financ. 2005, 11, 645-660. [CrossRef]

36. Holmström, B.; Tirole, J. Financial intermediation, loanable funds, and the real sector. Q. J. Econ. 1997, 112, 663-691. [CrossRef]

37. Lundstrum, L.L. Entrenchment, management, capital structure changes and firm value. J. Econ. Financ. 2009, 33, 161-175. [CrossRef]

38. Hart, O.; Moore, J. Debt and seniority: An analysis of the role of hard claims in constraining management. Am. Econ. Rev. 1995, 85, 567-585.

39. Myers, S.C. Determinants of corporate borrowing. J. Financ. Econ. 1977, 5, 147-175. [CrossRef]

40. Myers, S C. The Capital structure puzzle. J. Financ. 1984, 39, 575-592. [CrossRef]

41. Myers, S.C. Outside equity. J. Financ. 2000, 55, 1005-1037. [CrossRef]

(C) 2019 by the author. Licensee MDPI, Basel, Switzerland. This article is an open access article distributed under the terms and conditions of the Creative Commons Attribution (CC BY) license (http:/ / creativecommons.org/licenses/by/4.0/). 